\title{
Study on the Mechanism and Path of Integrating Craftsmanship Spirit Into Vocational Quality- oriented Education for Vocational Students
}

\author{
Xinyi Liu ${ }^{1}$, Jianchun $\mathrm{Li}^{2}$,* \\ ${ }^{1}$ School of Business, Macau University of Science and Technology, Macau, China \\ ${ }^{2}$ School of Mechanical Engineering, Guangdong Songshanpolytechic, Shaoguan, GuangDong, China \\ *Corresponding author. Email: 729152065@qq.com
}

\begin{abstract}
The paper summarizes the characteristics and connotation of the craftsmanship spirit, explore the factors influencing the cultivation and promotion of craftsmanship spirit in Higher vocational colleges ofChina. This paper will take craftsmanship spirit as the research object, take the cultivation of craftsmanship spirit as an important means to improve vocational quality education in higher vocational colleges, and explore the measures and paths to integrate craftsmanship spirit into vocational quality education.
\end{abstract}

Keywords: Craftsmanship spirit, Vocational colleges, Quality-oriented education

\section{INTRODUCTION}

The core meaning of craftsmanship spirit include the spirit of conscientious working, team cooperation and quality thought of pursuing excellence. Craftsmanship spirit is a strict code of conduct gradually accumulated by human beings' long-term interaction in manufacturing activities. "Craftsmanship spirit" is a popular concept in Chinese society in recent years, and has entered the discourse of national policy. Craftsmanship spirit is an important part of Xi Jinping's new socialist ideology with China's characteristics. It is the inheritance and innovation of Marx's theory of labor capital, Mao Zedong's theory of combining education with productive labor and Deng Xiaoping's theory of science and technology being the of first productivity. Carrying forward the craftsmanship spirit is a major strategic deployment of the 19th National Congress of the Communist Party of China. It is a key measure to realize China's transformation from a large country of human resources into a powerful country of human capital. There are great significances for the transformation and upgrading of China's manufacturing industry and achieve an industrial power.
1.1. Cultivating and carrying forward the craftsmanship spirit is a work highly valued and promoted by the Communist Party of China and the government

The report of the 19th National Congress of the Communist Party of China proposed to "build a team of knowledge-based, skilled and innovative workers, carry forward the craftsmanship spirit, and create a glorious social trend of labor and a professional atmosphere of excellence." At present, China is in a critical period of moving forward from a large manufacturing country to a powerful manufacturing country [1]. The contradiction between the urgent demand for talents and the lack of effective supply in industrial transformation and upgrading is very prominent. In May 2019, the Ministry of Education of Chinaissued the notice on Comprehensively Strengthening the work of Modern Apprenticeship. The paper calls for the guidance of $\mathrm{Xi}$ Jinping's new socialist ideology with China's characteristics, with fully implementing the party's educational policy, implementing the basic task of moral education, deepening the integration of production and education, and improving the professional skills [2].Craftsmanship spirit should start with vocational education. Integrating craftsmanship spirit into higher vocational education not only meets the needs of national 
development, but also conforms to the responsibility and mission of higher vocational education.

\subsection{Integrating craftsmanship spirit into higher vocational education is an urgent need for the high-quality development of vocational education}

After nearly 20 years of development, higher vocational colleges in China have played a great role in the cultivation of skilled talents and have been widely recognized by enterprises. However, according to a survey by the Chinese Academy of Social Sciences and MYCOS Research Institute in 2019, enterprises' satisfaction with the cultural literacy of higher vocational college graduates is $20 \%-40 \%$, which is far lower than their satisfaction with knowledge (80\%) and skills (60\%), mainly reflecting the graduates' love and dedication, hard work, sense of responsibility, discipline compliance, teamwork ability. There is still a big gap between cost and quality awareness. The craftsmanship spirit is something that is sadly lacking today [3]. This reflects the absence of vocational quality core competence training in the higher vocational talent training system. Vocational quality education courses are far away from the reality of vocational posts, with paying too much attention to the cultivation of "high skills" and ignoring the cultural function and humanistic role. Therefore, it is necessary to take the cultivation of students' professional quality such as "hard-working, integrity, professionalism, sense of responsibility and cooperative spirit" as an important vocational training goal, and honesty and trustworthiness, love and dedication, hard-working, sense of responsibility and team work are also the core content of craftsmanship spirit [4].

\section{THE QUESTIONNAIRE DESIGN, SAMPLE SELECTION AND DATA COLLECTION AND ANALYSIS}

\subsection{Survey status and interview questionnaire design. Investigation and influence factor analysis on cultivation of craftsmanship spirit in Higher vocational colleges of China}

Based on relevant vocational education theories and quality-oriented education theories, this study sorted out and analyzed the relevant influencing factors and main patterns of the cultivation of craftsmanship spirit in Higher vocational colleges of China. The content of the questionnaire for students was divided into two parts, the first part was the survey about the students' spirit of understanding, professional agreement and self assessment.we designed 10 questions, the index ofthis part was the professional spirit and identity, the degree of understanding and the spirit of self assessment, etc. The second part was to investigate the effect of external environment on students' cultivation of craftsmanship spirit in the learning process, and 15 questions were designed. The 25 questions in the questionnaire were set as a five-level scale (value was assigned to the question options, with 1 being the lowest degree and 5 being the highest degree), and the reliability of the 25 questions was statistically analyzed through the data collected by the statistical software SPSS21.0. The Cronbach's Alpha value of the questionnaire was 0.876 , indicating that the reliability of the questions and data in the questionnaire was relatively obvious, which can support the analysis and research of the paper.

The survey and interview were mainly conducted in the following five dimensions [5]: 1 . What do you think is the connotation of the craftsmanship spirit? 2. What do you think are the key factors for cultivating the craftsmanship spirit in college? 3. What aspects does our college carry out to cultivate craftsmanship spirit?4. What do you think are the factors that hinder the cultivation of craftsmanship spirit among students in your college? 5. How do you think our school should foster the spirit of craftsmanship?

Our research group selected 325 Higher Vocational Colleges which located separately in Shanghai, Beijing, Shenzhen, Wuhan, Guangzhou, Tianjin, Chongqing, Chengdu, Shenyang and Hangzhou for sampling survey, and selected leaders of relevant government departments, industry (Association) personnel, enterprise personnel, school teachers and students (including students in school and graduates) as the main representatives, Questionnaire survey and interview survey were conducted around the cultivation of craftsmanship spirit. The survey methods were door-to-door visits and online interviews.

Before the formal survey, a small range of pre-survey was conducted. A total of 80 copies were issued, with a recovery rate of $100 \%$ and all valid. Then the reliability and validity of the pre-survey questionnaire were tested. After passing the test, the formal survey was carried out A total of 1500 questionnaires were sent for formal survey and 52 focus interviews were conducted. In the end, a total of 1360 questionnaires were collected, 35 invalid questionnaires were removed, and the number of valid questionnaires was 1325 questionnaires. After the questionnaire was collected, it was input and statistically analyzed. The validity of the collected data was tested by the statistical software SPSS21.0, and the KMO test value of the survey data was 0.972 , which indicated that the questionnaire data was suitable for factor analysis.

\subsection{Analysis of impact factors and survey data}

Through the hypothesis structure model, path analysis and calculation of the path coefficient of the hypothesis structure model, this study verified and analyzed the structural relationship of influencing factors 
on the cultivation of craftsmanship spirit in higher vocational colleges of China, compared the relative importance of various influencing factors, and calculated the direct and indirect influence between variables. AMOS7.0 was used as the data analysis tool in the study. Through the analysis of the key characteristics of the factors affecting the cultivation of the craftsmanship spirit in higher vocational colleges, as well as the analysis of interview materials and survey data, the model and path of integrating the craftsmanship spirit into the vocational quality education of higher vocational students were put forward and verified.

\section{REGRESSION ANALYSIS OF INFLUENCING FACTORS ABOUT CULTIVATION AND PROMOTION OF CRAFTSMANSHIP SPIRIT}

Through regression analysis, we can sort the influence degree of various factors affecting the lack of craftsmanship spirit, and get the most significant factors, then suggestions were put forward in order to cultivate craftsman's spirit. This study takes craftsman's spirit as dependent variable and school environmental factors, enterprise environmental factors and social environmental factors as independent variables for linear regression. As shown in Table 1, the adjusted $\mathrm{R}$ square is 0.398 , the $\mathrm{F}$ value is 39.274 , and the $\mathrm{P}$ value is 0.000 , which is statistically significant. It shows that the linear fitting is good, the regression equation is also representative, and the independent variable has a good interpretation of the dependent variable.

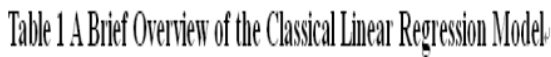

\begin{tabular}{|c|c|c|c|c|}
\hline \multirow{2}{*}{ Model $R \quad R^{2}$ Changed $R$} & Deriation from standadedestimates & \multicolumn{3}{|c|}{ Changed statisicical variables } \\
\hline & & Fralued & f & $P$ \\
\hline $\begin{array}{llll}1 & .6358 & .403 & 398\end{array}$ & 2.56321 & 39.856 & 1319 & .0000 \\
\hline
\end{tabular}

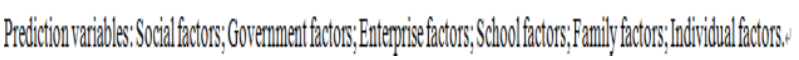

The ranking results of the influencing factors on the craftsman's spirit are shown in Table 2. The magnitude of the $\beta$ value reflects the magnitude of the influencing factors. Therefore, the ranking of the influencing factors on the craftsmanship spirit is as follows by observing the magnitude of the $\beta$ value: Social factors, Government factors, School factors, Enterprise factors, Individual factors and Family factors, among which Social factors are the primary influencing factors of craftsmanship spirit, and the analysis shows that the Government factors and other factors are positively correlated to the influence of craftsmanship spirit.
Table 2 The order of importance of factors influencing the cultivation of craftsmanship spirit-

\begin{tabular}{c|cc|c|c|c}
\hline \multirow{2}{*}{ Model } & Nonnormalized coefficient & $\begin{array}{l}\text { Normalization } \\
\text { coefficient }\end{array}$ & \multirow{2}{*}{ t-value } & P-value \\
\cline { 2 - 3 } & \multicolumn{2}{|c|}{$\beta$ Standard error } & Beta & & \\
\hline 1 (constant) & .679 & .064 & & 4.503 & .000 \\
Social factors & .302 & .012 & .028 & 2.241 & .000 \\
Government factors & .265 & .017 & .052 & 3.542 & .000 \\
School factors & .167 & .001 & -.038 & 3.103 & .008 \\
Enterprise factors & .132 & .001 & .019 & 2.103 & .011 \\
Individual factors & .134 & .045 & .062 & 2.052 & .000 \\
Family factors & .115 & .023 & -.019 & 2.114 & .002 \\
\hline
\end{tabular}

\section{SUGGESTIONS AND MEASURES}

The path and strategy of integrating craftsman's spirit into vocational quality education for vocational students

The Fourth Plenary Session of the 19th Communist Party of China Central Committee clearly stated: "Carry forward the scientific spirit and the craftsman's spirit, speed up the construction of an innovative country, strengthen the technology power of national strategy improve the national laboratory system and build a new nationwide system for tackling key and core technologies in a socialist market economy". It is the first time to put the spirit of craftsmanship together with the spirit of science, which highlights the importance of carrying forward the craftsmanship spirit for building an innovative country. With the change of times and the demand of economic development, we should not only pay attention to the cultivation and training of the "skills" of the craftsmen, but also follow up the shaping and cultivation of the "morality" of the craftsmen, namely the cultivation and promotion of the craftsmanship spirit. Through the analysis conclusion of the previous research, different degree of importance is in proper order [6]. It is respectively the social factors, government factors, school factors, enterprise factors, individual factors and family factors that have a positive correlation with the cultivation of the craftsmanship spirit. The research shows that the cultivation and promotion of the craftsmanship spirit need all parties to play a synergistic role and jointly promote the integration of the craftsmanship spirit into the vocational quality education of vocational students.

\subsection{Society needs to build an environment that respects the craftsmen and improve their social identity}

Through empirical analysis, it is concluded that social environment is the most influential factor of craftsman's spirit. In order to cultivate and promote the spirit of craftsmanship, we need to foster the social atmosphere in which skilled personnel are respected and respected, 
guide the whole society to respect, value and care about the training and growth of skilled personnel, and encourage young people to become skilled and serve the country with their skills. We should publicize the important contribution and role of skilled personnel, advocate the trend of "respecting reality and industry" in the whole society, foster the social atmosphere of respecting skilled personnel, and make it a social consensus to respect labor, technology and creation. By organizing the excellent skilled talents into schools, enterprises, and communities, the skilled talents can gain more sense of career honor, and it also drives more young people to pursue a skilled career. At the same time, public opinion guidance should be strengthened to publicize the contribution of skilled personnel. A group of skilled masters and craftsman should be recognized and rewarded to enhance their sense of pride. We should improve the social and political status of skilled personnel, and guide skilled personnel to actively participate in the administration of social affairs.

\subsection{The government should build an institutional system to ensure the career development of skilled personnel and strengthen the protection of intellectual property rights.}

System is the key factor for the cultivation of craftsmanship spirit. At the institutional level, craftsmen should be respected by society and get their due social status. Improving the social status and welfare treatment of craftsmen through system construction can guide people's concept consciousness, including the concept of study, employment and professional values. First of all, the government should provide the multi-directional policy support, which including improving the system of training, evaluating and motivating skilled personnel, vigorously develop vocational education, carrying out large-scale vocational skills training, and accelerating the training of a large number of high-quality workers and technical personnel. Secondly, the legislation should ensure the development of skills talents. Vocational education plays an important role in the national personnel training systemin accordance with the law. The responsibilities of governments at all levels should be defined, and the rights, responsibilities and obligations of vocational schools, industries and enterprises should be regulated. Relevant laws and regulations should also be improved to protect the legitimate rights and interests of craftsmen to the greatest extent possible by means of laws and systems. Finally, it is necessary to promote the reform of the system related to skilled talents, and promote the reform of the cultivation and assessment of new skilled talents in order to adapt to the upgrading of technological innovation and social development.

The intellectual property system is a great invention of mankind and a historical phenomenon of the development of productive forces and science and technology. At the same time, as a non-reproducible intangible resource, intellectual property plays an important role in protecting the relevant interests of individuals or enterprises. The intellectual property system emphasizes that knowledge is valuable and rewarding, pays attention to the personality of knowledge creators, and encourages independent thinking and independent innovation. We should strengthen our awareness and ability to respect others' intellectual property rights and protect their legitimate rights and interests, make disclosure of IPR protection information timely, and improve the level of IPR legislation and enforcement.

\subsection{The government, industry and enterprises cooperate to broaden channels for professional development of skilled personnel and build a platform for the growth of skilled personnel.}

Career development is the primary concern of all kinds of talents. The government, industries and enterprises should play the role of multiple actors to create a proper environment conducive to the growth and functioning of skilled personnel. First of all, we should improve the incentive mechanism of skilled talents, establish and improve the talent evaluation system with vocational qualification, vocational skill level determination and special vocational ability assessment as the main content. Secondly, we need to expand the career development channels for high-skilled talents. We should not only encourage more highly skilled personnel to participate in scientific research projects at all levels and carry out scientific and technological research activities, but also support highly-skilled personnel to participate in the selection and display of innovation achievements. Finally, the career promotion channels of skilled personnel should be opened up. Qualified highskilled personnel, especially those from small and micro enterprises, can participate in the evaluation of professional titles of engineering series technical personnel. We will encourage enterprises to explore the creation of positions exclusively for skilled personnel such as "chief technician," "skill expert," and "craftsman," and expand the rank promotion channel for skilled personnel.

\subsection{Vocational colleges should deepen the reform of talent training mode, promote the integration of industry and education, and innovate the mode of school-enterprise cooperation.}

An important part of the craftsmanship spirit is the professional spirit and the ability to strive for perfection and pursue every detail. Vocational colleges should combine the improvement of vocational skills with the 
cultivation of professional spirit, it is not only to teach students skill, but also to nurture spiritual self-cultivation and establish personality. In the practical link of higher vocational education, in addition to the curriculum practice arranged by higher vocational colleges, it also needs to rely on enterprises to enrich students' practical experience. The talent training mode must be jointly formulated and trained by both the school and the enterprise according to the market demand. During this period, the emphasis is placed on cultivating students' professional quality and job skill, so that modern apprenticeship can be made into an important way to cultivate technical talents. During the internship, the enterprise can enroll outstanding students through the assessment of the student performance. This method can stimulate the motivation and enthusiasm of students during the internship to a large extent, enterprises can also save material and human resources for recruitment, and optimize resource allocation.

\subsection{Vocational colleges should reconstruct curriculum framework, adjust the teaching contents and teaching methods.}

Higher vocational education aims at cultivating skilled personnel working at manufacturing job with strong practical ability. Moreover, higher vocational education must meet the needs of the economic development. Therefore, higher vocational education has the destined responsibility for cultivating the craftsmanship spirit. Based on employee-orientation, Vocational colleges cultivate practical talents with high professional quality. However, the craftsmanship spirit in professional quality is often ignored by vocational colleges, which just focus on the knowledge learning and cultivation of professional skills. Therefore, the cultivation of craftsmanship spirit should be carried by the education and training of higher vocational colleges, such as reconstructing the curriculum framework, and adjusting the teaching content and methods. First of all, vocational colleges instill the craftsmanship spirit through ideological courses and career guidance courses. Teachers transmit correct professional values to students and plan their own career in the process of teaching. Secondly, we should carry out the key education on craftsmanship spirit, and gradually internalize the spirit of craftsman in everyone's mind by organizing students to participate in reports and seminars. Finally, the craftsmanship spirit should be integrated into the teaching process of professional courses, so that students can comprehend the professional qualities and the importance of different positions, and incorporate them into the assessment and evaluation in daily life. the craftsmanship spirit of students can be cultivated through the gradual integration of professional course teaching and professional spirit education
4.6 The enterprise should condense the culture of "respecting reality and industry", reform the salary system, effectively improve the material benefits of the skilled personnel.

The building of enterprise culture has promoting effect on the cultivation of the craftsmanship spirit, the connotation of the craftsmanship spirit and the enterprise culture will form a kind of common values in the enterprise, which consciously train your employees to pay attention to the details of their daily work, cultivate the honor sense of employees, and thus generate tremendous potential. One of the main reasons for the shortage of highly skilled personnel in Chinese enterprises is low income, which inhibits the enthusiasm of employees to study technology and the development of skilled personnel. On the one hand, effectively improving the economic benefits of skilled personnel can strengthen the participation of skill shares in the distribution. For example, we will explore the ways of salary agreement, shareholding and dividend sharing, annual salary system, equity system and tenure system, so that skilled personnel can fully enjoy the significant benefits brought their professional skills. On the other hand, it is necessary for the government, enterprises and society to implement the policy together and unleash the vitality of the system and comprehensively improve the benefits of technical personnel. It is also the keyway of cultivating the craftsmanship spirit, specifically, which is to ensure that technical personnel can enter the middle income class and the High-level craftsman can enter the high income class.

\subsection{The family should build a family culture of strong faith, dedication, integrity and harmony, and foster the positive family atmosphere.}

Family is the basic cell of society and the first school for everyone. Every change of family culture involves the traditional family virtues of the Chinese nation, and includes the people's longing for a better life, and reflects the historical track of the country's continuous development and progress. It is an innovative way that stresses nurturing family culture with firm belief, dedication, integrity and harmony. The mainstream value orientation of the family plays an important guiding role in the career planning of the members. At the same time, the family tradition of respecting technology and science is advocated, and the excellent personal qualities including conscientiousness, dedication, persistence and innovation become the career pursuit of the family members. The theme of Chinese family style is craftsmanship, it is virtues that could facilitate national development in the new era. The craftsmanship spirit can make people have more endurance, with a tireless attitude to life and work. Family culture should also make family members deeply feel that the craftsmanship spirit is not 
far away and strange, it appears in our jobs and daily life of every one. As long as we persevere, work hard and bear hardships, every ordinary person can become a highly-skilled craftsman who practices the craftsmanship spirit.

\subsection{Individuals should enhance their value cognition of highly skilled talents and establish good career outlook and employment attitude.}

Only the craftsmen feel the significance and value of their work can they truly pursue their ownership spirit, improve the quality of their work consciously and spontaneously, and create greater benefits for enterprises and the society. There is no high or low level of position, but there is a high or low level job.if the workers themselves cannot take their work seriously, It is natural that they cannot gain the respect of others. Enterprises should foster a positive and enterprising craftsmanship culture and advocate the spirit of crafting and pursuing perfection. Only when craftsmen respect themselves can they win the respect of enterprises and society. Therefore, the cultivation of craftsmanship spirit for individuals is conducive to the establishment of career development view and employment attitude. First of all, we should abandon the impetuous mentality, and carry out practical activities in a down-to-earth manner with a nonutilitarian attitude. Secondly, we should find pleasure in our daily work, that is to say, we love what we do, devote ourselves to study and work with full enthusiasm, and complete our own work seriously and responsibly, so as to improve our own competitiveness in employment and realize our personal value.

\section{CONCLUSIONS}

Only by stepped up efforts for the growth of skilled personnel can the "flower of craftsmen" blossom. Society needs to nurture an environment of respect for artisans and strengthen their social identity; The government should build a system to ensure the growth of skilled personnel and strengthen the protection of intellectual property rights. The government, industry and enterprises cooperate to broaden the channels of professional development of skilled personnel and build a platform for the growth of skilled personnel; Vocational colleges should deepen the reform of talent training mode, innovate the integration of industry and education and school-enterprise cooperation mode; Vocational colleges should reconstruct the curriculum framework, adjust the teaching content and teaching methods; The enterprise should condense the culture of "respecting reality and industry", reform the salary system, effectively improve the material benefits of the skilled personnel; The family should foster a family culture of firm belief, dedication, integrity and harmony, and cultivate a family atmosphere of positive energy; Individuals should enhance their cognition of the value of highly skilled talents and establish good career outlook and employment attitude.

We need make the "craftsmanship spirit" as "hot" word among young people, and make young skilled workers who are highly-skilled talent respected and sought after by the society. We need vigorously promote the craftsmanship spirit and encourage young people to serve the country with their skills.

\section{ACKNOWLEDGMENTS}

This study was financially supported by 2021 Social science planning project of Shaoguan city (No. Z2021008) and 2020 University-level Quality Engineering Project of Guangdong Songshan Polytechnic (Education and Teaching Reform ProjectNo. 2020JYJG3)

\section{REFERENCES}

[1] Liyuan Wang. Necessity and Feasibility of Cultivating Students' Craftsmanship spirit in Higher Vocational Education. Vocational Education Forum,2014, pp.43-47

[2] Xiaoyan Yang.Exploration and Practice of Modern Apprenticeship. Vocational Education Forum,2012(9), pp.17-18.

[3] Zirui Zhang, Fan Kai. Introduction to craftsmanship spirit and Cultivation of Craftsmanship spirit. Beijing: Democracy and Construction Press,2017, pp.36-45

[4] Jianjun Zhou, Ping Sun. Craftsmanship spirit: Enhancing humanistic quality and professional ethics education of medicine. China Vocational and Technical Education,2016(20), pp.42-44.

[5] Zhijun Zang.Two Kinds of Craftsmanship spirit. Vocational Education Communication,2015(28), pp. 10

[6] Koran Zhang.The Impact of Traditional Apprenticeship on the Development of Modern Apprenticeship. Journal of Higher Education,2015 (24), pp.168-169. 